\title{
Analysis of Inland Aquaculture Sector in Çankırı Province, Problems and Solution Suggestions
}

\author{
Çankırı İlinin Su Ürünleri Sektör Analizi, Sorunlar ve Çözüm Önerileri
}

\begin{tabular}{|c|c|c|}
\hline \multicolumn{3}{|c|}{ Arda ÖZEN* } \\
\hline - Geliş tarihi / Received: 03.04.2019 & - Düzeltilerek geliş tarihi / Received in revised form: 28.08.2019 & - Kabul tarihi / Accepted: 13.09.2019 \\
\hline
\end{tabular}

\begin{abstract}
The aim of this study was to assess the current status of inland aquaculture in Çankırı province by using the SWOT (Strengths, Weaknesses, Opportunities, and Threats) analysis technique and to provide recommendations for making aquaculture to be more effective in the future. SWOT analysis was based on the data that was obtained from interviews with the owners of the aquaculture facilities, literature data and observations from field studies. Establishing fisheries cooperatives, subsidizing the fish production costs of fish farms, preparing province scaled management and production plans for fisheries, monitoring water resources for securing the water quality, changing consumer's preferences are necessary for improving the Çankırı aquaculture sector. The results further showed that, Çankırı province has a high potential for the inland aquaculture sector in the future if strengths and opportunities are used effectively and internal weaknesses are improved by reducing the impact of the external threats in planning.
\end{abstract}

Anahtar kelimeler: Aquaculture, Çankırı, Fish Production, Inland Waters

$\ddot{O} z$

Bu çalışmanın amacı, Çankırı ili su ürünleri sektörünün mevcut durumunu, GZFT analizi (Güçlü ve Zayıf Yanlar, Fırsatlar ve Tehditler) ile değerlendirmek ve gelecekte sektörü daha etkin hale getirebilmek için çözüm önerileri sunmaktır. GZFT analizi su ürünleri tesislerinin sahipleri ile yapılan görüşmelere, literatür verisine ve arazide elde edilen gözlemlere dayanmaktadır. Illde sektördeki sorunların üstesinden gelebilmek için alınabilecek tedbirler: su ürünleri kooperatifleri kurmak, balık çiftlikleri için üretim maliyetlerini azaltacak özel indirimler sağlamak, Çankırı ili genelinde balık üretim planlamaları yapmak, su kaynaklarının kalitesinin sürekli izlenmesi, halkın gıda tüketim alışkanlıklarını değiştirmek. Sonuç olarak, ĕger sektörün güçlü yanları ve firsatlar etkili kullanılabilirse ve zayıf yanlar olası tehditleri de dikkate alarak geliştirilebilir ise Çankırı ili su ürünleri sektörü gelecekte gelişmek için büyük bir potansiyele sahiptir.

Keywords: Su Ürünleri Yetiştiriciliği, Çankırı, Balık Üretimi, İ̧̧ Sular

*Arda ÖZEN, ardaozen@gmail.com, Phone: (0505) 60726 13; orcid.org/0000-0001-5315-8424 


\section{Introduction}

Fish is one of the oldest food sources of human. While production from capture fisheries is decreasing, the contribution of fish supply from aquaculture is increasing. The most important factors for the development of aquaculture in the world are the rapid growth of the population, the need, and demand for healthy food, employment, growing export and other socioeconomic factors (Akova, 2015).

However, although the importance of aquaculture increases, the waters have been polluted and used unconsciously without complying with the legal regulations. The importance of aquaculture in seas and inland waters is increasing rapidly since the beginning of the 21 st century due to the degradation of natural water resources and the beginning of fishing in open seas with various technological developments (Yüngül et al., 2012). Thus, existing water resources should be used in optimum level in order to gain the maximum yield of aquaculture production (Akbulut et al., 2009).

In line with the development of aquaculture in Turkey, aquaculture studies started in the 1990s in Çankırı province. Unfortunately, despite to the great potential of the aquaculture, the sector in Çankırı did not show any progress in recent years. In the literature there were similar studies to assess the fisheries sector in Turkey (Akça et al., 2006; Çelik et al., 2012) and different provinces such as Burdur (Gümüş et al., 2009), Antalya (Gümüş and Yılmaz, 2011), Muğla (Özdemir and Dirican, 2006) by using SWOT analysis but there has not been any similar study for Çankırı province. The aim of this study is to analyse the current status of Çankırı's aquaculture sector by using SWOT analysis and make recommendations to improve this industry in the future.

\section{Materials and Methods}

Çankırı is a province of Turkey, which located in the north of Central Anatolia between Kizılırmak and West Black Sea watersheds, between $40^{\circ} 16^{\prime}$ and $41^{\circ} 04$ ' northern latitudes and between $32^{\circ}$ $34^{\prime}$ and $34^{\circ} 08^{\prime}$ east longitudes. The neighbors of the province are Bolu in the west, Karabük in the northwest, Kastamonu in the north, Çorum in the east and Ankara and Kirıkkale in the south. The altitude of province is 723 meters and it has an area of $7.388 \mathrm{~km}^{2}$. Çankırı has 12 districts (Central district, Atkaracalar, Bayramören, Çerkeş, Eldivan, Ilgaz, Kızılırmak, Korgun, Kurşunlu, Orta, Şabanözü and Yapraklı), (Çankırı İli Çevre Durum Raporu, 2018).

The province is situated in continental climate of Central Anatolia. It has an average temperature of $11.2{ }^{\circ} \mathrm{C}$, maximum temperature of $17.9{ }^{\circ} \mathrm{C}$, minimum temperature of $4.8{ }^{\circ} \mathrm{C}$, and an annual total precipitation of $403 \mathrm{~mm}$. The hottest months are July and August and the coldest months are January and February. Most of the precipitation occurs in May and minimum precipitation is observed in July (Cengil and Kuşvuran, 2012).

SWOT analysis, which is used in decisionmaking, is a useful strategic planning technique. SWOT stands for Strengths, Weaknesses, Opportunities, and Threats (Henricks, 1999; Houben et al., 1999). SWOT analysis describes the internal and external factors which have impacts on a specific topic (Pickton and Wright, 1998).

Therefore, SWOT allows one to see the sector's strengths and weaknesses with external opportunities and threats from a broad perspective (Duarte et al., 2006; Rothaermel, 2012).

In this study, Çankırı fishery industry was analysed by the SWOT analysis technique. Literature, statistical and field data were also used along with data from the SWOT analysis. Field observations were made in some manmade ponds, trout farms, and streams of Çankırı (Tatlıçay, Devrez, and Acicay). Also, interviews were made with the owners of trout farms in the province. Locations of trout farms are shown in Figure 1. Using the results of SWOT, the current status of the sector was determined, and recommendations were done to increase the potential of the sector.

\section{Results}

Çankırı is rich in natural water resources. 6036 hectares is covered by water in Çankırı (DSI, 2018). List of rivers and manmade ponds are given in Table 1 and Table 2, respectively. All manmade ponds are used for irrigation purposes. Alpsarı and Eldivan Karadere ponds are also used for recreation activities 


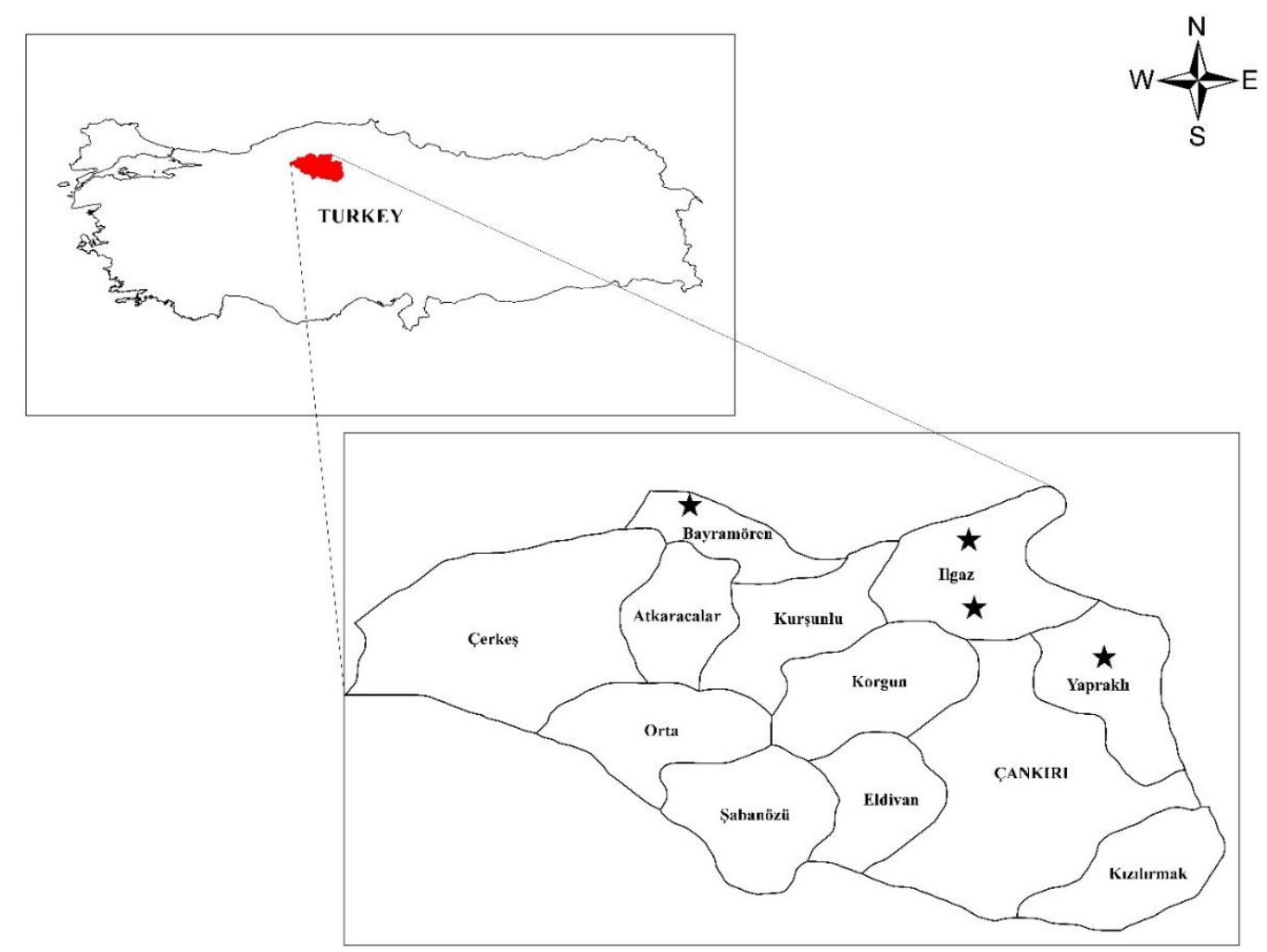

Figure 1. Locations of trout farms in Çankırı (marked with stars).

Table 1. Rivers of Çankırı province (DSİ, 2018)

\begin{tabular}{llllll}
\hline Creek name & $\begin{array}{l}\text { Total } \\
(\mathbf{k m})\end{array}$ & Length & $\begin{array}{l}\text { Length within } \\
\text { provincial borders } \mathbf{( k m )}\end{array}$ & $\begin{array}{l}\text { Flow } \\
\left(\mathbf{m}^{3} / \mathbf{s n}\right)\end{array}$ & Tributary of \\
\hline Kızılırmak & 1335 & 41 & 85 & \\
Acıçay & 113 & 113 & 3.4 & Kız1lırmak \\
Devrez & 160 & 85 & 8,9 & Kiz1lırmak \\
Ulusu & 52 & 52 & 1.5 & Gerede \\
Terme & 37.8 & 37 & 2.9 & Acıçay \\
Gerede +Melen & 89.6 & 89.6 & 17.3 & - \\
\hline
\end{tabular}

Table 2. Some properties of manmade ponds in Çankırı Province (DSİ, 2018)

\begin{tabular}{lll}
\hline Name of the pond & Pond area (ha) & Pond volume $\left.\mathbf{( m}^{\mathbf{3}}\right)$ \\
\hline Eldivan Sarayköy 1 & 5.0 & 332000 \\
Eldivan Karadere & 3.7 & 400000 \\
Eldivan Sarayköy 2 & 4.8 & 544000 \\
Eldivan Seydiköy & 8.1 & 688000 \\
Şabanözü & 9.2 & 885000 \\
Şabanözü Karaören & 13.0 & 908000 \\
Şabanözü Mart & 3.9 & 535000 \\
Şabanözü Ödek & 4.0 & 236000 \\
Yapraklı & 2.8 & 279000 \\
Korgun Maruf & 10.0 & 871000 \\
Kurşunlu Demirciören & 2.0 & 119000 \\
Orta Dumanlı & 4.0 & 885000 \\
Kurşunlu Taşkaracalar & 6.8 & 308000 \\
Alanpınar & 12.0 & 1726000 \\
Yukarı̈̈z & 12.0 & 1955449 \\
Alpsar1 & 34.0 & 2291340 \\
Karacaözü & 6.0 & 500000 \\
Yakalı & 7.0 & 210000 \\
Ekinne & 14.0 & 1865000 \\
Yukarı̈öz & 20.0 & 1955000 \\
\hline
\end{tabular}


Natural lakes in Çankırı are small and temporary lakes. Most of them are saline and doline lakes. In Çankırı, there are 15 lakes namely Kamış, Hacılar, Uzun, Bozkara, Yayla, Hasır, Kürt, Pazar, Büyük, Dipsiz, Çöp, Bakkal, Gül, Suluk and Kadigil (Çankırı İli Çevre Durum Raporu, 2018). Lake Bakkal ,a doline lake, has been declared as a wetland area of local importance since 2017 (Çankırı İli Çevre Durum Raporu, 2018). These lakes are not proper for fishing activities and aquaculture production. The contribution of Çankırı to inland fisheries production is very low (Table 3).

Table 3. Inland fisheries production in Turkey and Çankırı between 2000 and 2017 years (TÜİK, 2018).

\section{Chub (tone/year) Common carp (tone/year)}

\begin{tabular}{lllll}
\hline Year & Turkey & Çankırı & Turkey & Çankırı \\
\hline $\mathbf{2 0 0 0}$ & 698 & 2 & 14137 & 305 \\
$\mathbf{2 0 0 1}$ & 710 & 2 & 12265 & 297 \\
$\mathbf{2 0 0 2}$ & 659 & 2 & 12965 & 299 \\
$\mathbf{2 0 0 3}$ & 738 & 3 & 13820 & 310 \\
$\mathbf{2 0 0 4}$ & 820 & 2 & 13451 & 283 \\
$\mathbf{2 0 0 5}$ & 830 & 2 & 13718 & 283 \\
$\mathbf{2 0 0 6}$ & 948 & 2 & 12116 & 241 \\
$\mathbf{2 0 0 7}$ & 927 & 1 & 12286 & 237 \\
$\mathbf{2 0 0 8}$ & 1023 & 1 & 11625 & 221 \\
$\mathbf{2 0 0 9}$ & 970 & 1 & 10964 & 126 \\
$\mathbf{2 0 1 0}$ & 1512 & 1 & 12058 & 131 \\
$\mathbf{2 0 1 1}$ & 1325.3 & 1 & 9998.1 & 95 \\
$\mathbf{2 0 1 2}$ & 1138 & 1 & 9973 & 100 \\
$\mathbf{2 0 1 3}$ & 1094.4 & 1.5 & 8276.6 & 70 \\
$\mathbf{2 0 1 4}$ & 1192 & 2 & 8036 & 73 \\
$\mathbf{2 0 1 5}$ & 1161 & 1 & 7223 & 65 \\
$\mathbf{2 0 1 6}$ & 1136 & 1 & 4736 & 40 \\
$\mathbf{2 0 1 7}$ & 1424 & 1 & 3543 & 25 \\
\hline
\end{tabular}

Interviews were made with the trout farmers in 2017 to determine problems of the sector (Table 4). All the trout farms were family companies and not managed by professionals. All of them were working at full capacity except the Çayır trout farm. Total production was 35 ton/year in Çankırı.
High fish production cost, problems of marketing and lack of technical staff were the main common problems of the trout farms. They also complain about the inadequacy of governmental financial supports and inadequate access to available financial supports.

Table 4. Problems and capacity of trout farms in Çankırı (2017)

\begin{tabular}{|l|c|c|c|c|}
\hline & $\begin{array}{c}\text { Cayir Trout } \\
\text { Farm (Ilgaz) }\end{array}$ & $\begin{array}{c}\text { Hayta Trout Farm } \\
\text { (Bayramören) }\end{array}$ & $\begin{array}{c}\text { Ehli Keyf } \\
\text { Trout Farm } \\
\text { (Yapraklı) }\end{array}$ & $\begin{array}{c}\text { Erkocalar } \\
\text { Trout Farm } \\
\text { (Ilgaz) }\end{array}$ \\
\hline Capacity (Ton/year) & 25 & 20 & 5 & 5 \\
\hline Production (Ton/year) & 5 & 20 & 5 & 5 \\
\hline Pond type & Concrete & Concrete & Concrete & Concrete \\
\hline Water resource & Creek water & Spring water & Spring water & Creek water \\
\hline Extrude feed consumption & + & + & + & + \\
\hline Number of Employee & 4 & 5 & 10 & 5 \\
\hline $\begin{array}{l}\text { Trout farms } \\
\text { management types }\end{array}$ & Private Property & Private Company & Private Property & Property \\
\hline
\end{tabular}


Table 4. continued

\begin{tabular}{|c|c|c|c|c|}
\hline & $\begin{array}{l}\text { Çayır Trout } \\
\text { Farm (Ilgaz) }\end{array}$ & $\begin{array}{c}\text { Hayta Trout Farm } \\
\text { (Bayramören) }\end{array}$ & $\begin{array}{l}\text { Ehli Keyf } \\
\text { Trout Farm } \\
\text { (Yapraklı) }\end{array}$ & $\begin{array}{c}\text { Erkocalar } \\
\text { Trout Farm } \\
\text { (Ilgaz) }\end{array}$ \\
\hline Road type to the farms & Asphalt & Stabilized & Asphalt & Stabilized \\
\hline $\begin{array}{l}\text { Trout farms according to } \\
\text { financial resources }\end{array}$ & Own resources & $\begin{array}{c}\text { Own resources and } \\
\text { credit }\end{array}$ & $\begin{array}{c}\text { Own resources and } \\
\text { incentive }\end{array}$ & Own resources \\
\hline Type of trout facilities & $\begin{array}{l}\text { Production with } \\
\text { hatcheries }\end{array}$ & $\begin{array}{l}\text { Production } \\
\text { with } \\
\text { hatcheries }\end{array}$ & Production & $\begin{array}{l}\text { Production } \\
\text { with } \\
\text { hatcheries }\end{array}$ \\
\hline Lack of Technical staff & + & + & + & + \\
\hline High Production Cost & + & + & + & + \\
\hline Marketing problem & + & + & + & + \\
\hline $\begin{array}{l}\text { Lack of knowledge about } \\
\text { governmental financial } \\
\text { support. }\end{array}$ & + & - & - & + \\
\hline
\end{tabular}

Although the increased amount of Trout produced by aquaculture in Turkey was increased from 2000 to 2017, there was a decreasing trend in Çankırı between 2000 and 2017 (Figure 2), which may be attributed to the following points:

- Decreased market shares due to the increased trout facilities in the neighbouring provinces
- Decrease in Regional Investment Incentives in Aquaculture Production and increase in investment for beekeeping and cattle breeding

- Increased in production costs

- Bankrupt of the trout farm facility in Bayramören in 2013 and 2016 and interruption of production for a while (20000 ton/per year).

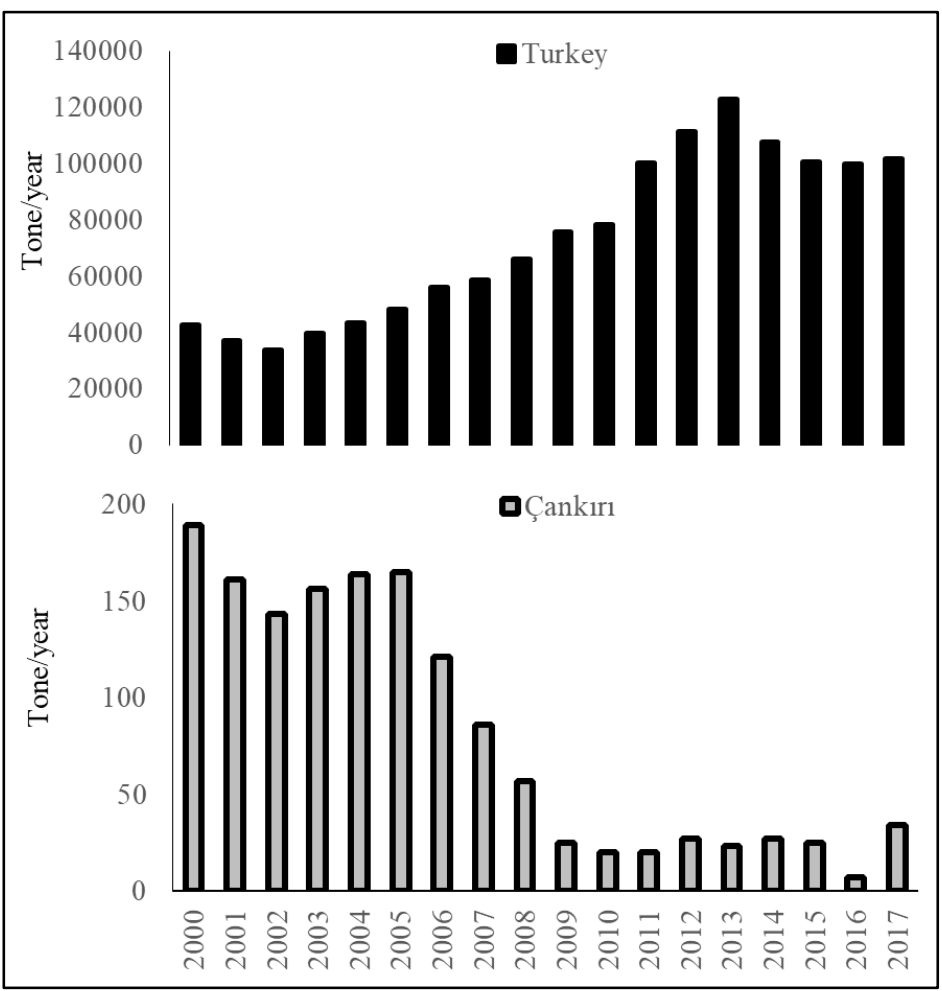

4 Figure 2. Comparison of the amount of the trout produced by aquaculture in Turkey and Çankırı between 2000 and 2017 years (TÜİK, 2018) 
Ilgaz and Yapraklı districts and Tatlıçay and Devrez tributaries were most suitable for trout farming according to the field observations. Location of present trout farms was chosen properly. Manmade lakes were suitable for sports fishing and potential for leisure and have potential tourism activities, especially those located in Eldivan, Korgun and Yapraklı districts.
Manmade lakes in Şabanözü district were not suitable for trout farming since their catchment surrounded by agricultural areas. Manmade lakes that were surrounded by forest were also proper for trout farming in Eldivan district. Results of The SWOT analysis Çankırı aquaculture sector were given in Table 5 .

Table 5. Results of The SWOT analysis Çankırı aquaculture sector

\begin{tabular}{|c|c|c|}
\hline & Positive & Negative \\
\hline & $\begin{array}{l}\text { Strengths } \\
\text { - Rich in clear inland water resources for } \\
\text { aquaculture } \\
\text { - Low transport costs to main metropolitan } \\
\text { cities } \\
\text { - Having advanced transportation networks } \\
\text { (highway and railway) } \\
\text { - Continuing the construction of new } \\
\text { ponds and dams (13 ponds and } 1 \text { dam are } \\
\text { under construction) } \\
\text { - High leisure and tourism potential } \\
\text { especially for sport fishing } \\
\text { - The sector is still in its infancy and is still } \\
\text { open to the development }\end{array}$ & $\begin{array}{l}\text { Weaknesses } \\
\text { - Fish consumption of local people and fish } \\
\text { market are still inadequate in the province } \\
\text { - Unqualified employees and workers in the } \\
\text { sector } \\
\text { - Lack of technical staff and technical support } \\
\text { - Lack of product marketing to near cities. } \\
\text { - Full capacity production not possible due to } \\
\text { - The low marketing and promotion } \\
\text { - The lack of aquaculture farming cooperatives } \\
\text { - The lack of professional management of } \\
\text { trout farms. non-professional family farming } \\
\text { - The lack of comprehensive studies on the } \\
\text { potentials of water resources on the } \\
\text { aquaculture fisheries } \\
\text { - The inability to utilize full capacity from } \\
\text { - Inisting water resources } \\
\text { - Thadequate monitoring and data deficiencies } \\
\text { of water resources } \\
\text { the culture trout that it will be less flavourful } \\
\text { - And healthy. } \\
\text { professional sector in the province. }\end{array}$ \\
\hline 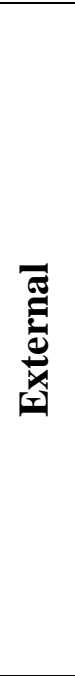 & $\begin{array}{l}\text { Opportunities } \\
\text { - Availability of some economic } \\
\text { incentives and supports from } \\
\text { Government } \\
\text {-Rural development investment } \\
\text { programs } \\
\text {-EU agriculture and rural development } \\
\text { support assistance agency } \\
\text { - National Investment Incentives for } \\
\text { Aquaculture Production } \\
\text { - Agricultural credit cooperatives } \\
\text {-Increasing fishing demand with } \\
\text { increasing population in Turkey }\end{array}$ & $\begin{array}{l}\text { Threats } \\
\text { - High fish bait price } \\
\text { - The monopoly of fish bait company } \\
\text { - Low-quality fish bait } \\
\text { - High fish production cost } \\
\text { - Instability in exchange rates } \\
\text { - Water quality degradation in drought } \\
\text { periods }\end{array}$ \\
\hline
\end{tabular}




\section{Discussion}

Aquaculture sector has a great potential to grow and still needs to be improved in Turkey (Çelik et al. 2012). The contribution of inland aquaculture production to the total fish production was increased from $1.1 \%$ in 1990 to $16.5 \%$ in 2017 (TÜIIK, 2018), while trout production trend in Çankırı showed a decreasing trend in the same period. The main weaknesses of the sector were inadequate management of trout farming, lack of qualified staff and marketing related problems.

Marketing problems mainly arisen from low fish consumption in the city as well as in Turkey (Çelik et al., 2012). The trout consumption is relatively low in Çankırı due to preconceptions on the quality and healthiness of cultured trout and deficiencies in local fish marketing despite fish (trout) have a price advantage over red and white meat. Changing consumer's food preferences or reducing the biased thoughts on fish food will increase the fish consumption in the city. For example, even a half $\mathrm{kg}$ increase in per capita consumption of trout in the city will create an additional demand of 90 tons, which is threefold of current production. To increase fish consumption in the province:

*The importance of fish consumption for human health should be advertised in public areas such as in schools and government offices to increase public awareness on fish consumption.

*More fish sale points should be open in the province.

* Fish meat consumption should be encouraged instead of red meat consumption by doctors and dietitians

* Through sportive fishing, people should be encouraged to fish consumption.

High fish production cost (high fish bait, the monopoly of fish bait companies), low-quality fish baits were the main threats of fish production in the region. High bait prices are one of the leading financial and technical problems experienced by producers in both Çankırı and other regions of Turkey (Özdemir and Dirican, 2006). There is no fisheries cooperative in the city, which can be an effective instrument for solving marketing and high production. Members of a cooperative can increase product quality, bargaining \& purchase power, market access, and ultimately profitability. Cooperatives can offer members education and training to improve productivity, as well as on how to improve product quality. Cooperatives can organize the marketing issues (process, store, advertise, and sell its members' product). Members of a cooperative can gain access to new markets by pooling catch, can guarantee buyers they will have the needed volume of product. They can also organize purchasing issues (reducing costs of goods, supplies, and services by pooling their members' orders to improve their negotiating position with suppliers, buying cheaper fish baits, gear, and other necessities). Cooperatives can reduce each member's financial risk such as bankrupts of their members. Lack of qualified employees and workers in the sector was also the other weakness of the sector in Çankırı as well as in Turkey (Çelik et al., 2012).

Although having rich water resources was an opportunity for the province, there was not any study on production capacity of these resources. The SWOT results suggested that monitoring studies must be implemented for the evaluation of Water Quality of man-made lakes and Carrying Capacity for Trout Culture must be estimated according to these results. Production capacity might be improved by doing these studies. Constructing new plants in net cages built in ponds also might increase the trout production of Çankırı like in Gümüşhane (Aydın, 2014). Places, where cages will be placed in ponds, should be determined by scientific methods.

Specific steps should be taken to solve all these problems. The following measured may be taken in this regard: establishing fisheries cooperatives, subsidizing production costs of fish farms, planning of fisheries management and production plans at regional scale, implementing water resources monitoring studies, changing consumer food preferences.

To sum up, SWOT analysis of Çankırı revealed that the problems in the sector were very similar to that of Turkey such as insufficient qualified employees in sector, marketing problems and financial difficulties (Çelik et al., 2012). However, environmental pollution is not a potential threat in Çankırı in contrast to in Turkey. Most of the water resources in the province are in a good water quality due to low industrial activities. The recommendations of this study for aquaculture sector of Çankırı might be also applied in other provinces which have the similar problems and threats with Çankırı. In conclusion, Çankırı will have a great potential to improve the aquaculture and sport fishing sectors in the future if the external opportunities are used with strengths and 
internal weaknesses are improved by considering the disadvantages of external threats.

\section{Acknowledgments}

The first version of this study was presented as an oral presentation at "International Limnofish Symposium" between 4-6 October 2017 in Isparta, Eğirdir, TURKEY and it has been expanded into manuscript form with updated data.

\section{References}

Akbulut, B., Kurtoğlu, I.Z., Üstündağ, E. and Aksungur, M., 2009. Historical development and future projection of fish culture in Black Sea Region. Journal of FisheriesSciences.com, 3 (2), 76-85.

Akca, H., Kayim, M., and Sayili, M., 2006, Swot Analysis of Fishery Sector in Turkey, Journal of Applied Sciences, 6(8), 1863-1867.

Akova, B.S., 2015. Aquaculture and Its Distribution in Turkey. Journal of Aquaculture Engineering and Fisheries Research, 1 (4), 160-190.

Aydın, H., 2014. Gümüşhane İli Su Kaynakları ve Su Ürünleri Sektörünün Mevcut Durumu. Gümüşhane Üniversitesi Fen Bilimleri Enstitüsü Dergisi, 4 (2), 176-182.

Cengil, B., Kuşvuran, Ş., 2012. Sürdürülebilir tarım açısından Çankırı ikliminin değerlendirilmesi. Tarım Bilimleri Araştırma Dergisi 5(1), 166169.

Çankırı İli Çevre Durum Raporu, 2018. Çankırı Valiliği. İl Çevre ve Şehircilik Müdürlüğü. $143 \mathrm{~s}$.

Çelik, A., Metin, I. and Çelik, M., 2012. Taking a Photo of Turkish Fishery Sector: A Swot Analysis, Procedia - Social and Behavioral Sciences, 58, 1515-1524.

DSİ (Devlet Su İşleri), 2018. 5. Bölge Müdürlüğü, 52. Şube
Müdürlüğü,http://bolge05.dsi.gov.tr/isletmedeki tesisler

Duarte, C., Ettkin, L.P., Helms, M.M. and Anderson, M.S., 2006. The challenge of Venezuela: a SWOT analysis, Competitiveness Review, 16 (3/4), 233-247.

Gümüş, E., Gülle, İ., and Yüksel, O., 2009. Aquaculture in Burdur Province and its potential. E.U. Journal of Fisheries \& Aquatic Sciences, 26: 281-286.

Gümüş, E., and Yılmaz, S. 2011. Marketing and Aquaculture Sector in Antalya Province. The Journal of Graduate School of Natural and Applied Sciences of Mehmet Akif Ersoy University, 3: 15-31.

Henricks, M., 1999. Strength, weakness opportunity threat analysis. Entrepreneur, 27, 72-72.

Houben, G., Lenie, K. and Vanhoof, K., 1999. A knowledge-based SWOT analysis as an instrument for strategic planning in small and medium-sized enterprises. Decision Support Systems, 26, 125-135.

Özdemir, N. and S. Dirican, 2006. Muğla İlinde Kültür Balıkçılı̆ğ ve Sorunları. Ege Üniversitesi Su Ürünleri Dergisi,23(1/2), 283-286.

Pickton, D.W. and Wright, S. 1998. What's SWOT in the strategic analysis? Strategic Change, 7, 101109.

Rothaermel, F.T., 2012. Strategic Management: Concepts and Cases: London, McGraw-Hill Education-Europe, 960p.

TÜIKK (Türkiye İstatistik Kurumu), 2018. Su Ürünleri İstatistikleri, http://tuik.gov.tr/PreTablo.do?alt_id=1005

Yüngül, M., Harlığlu A.G. and Bağcı, E., 2012. Elazığ'da $\mathrm{Su}$ Ürünleri Sektörünün Günümüzdeki Durumu. Türk Bilimsel Derlemeler Dergisi, 5(1), 91-94. 